\title{
A Multidisciplinary Approach to Teaching: Historical- Architectural Research on Piazza Vittoria, Brescia
}

\author{
Un enfoque didáctico multidisciplinar: Investigación \\ histórico-arquitectónica de la Piazza della Vittoria, \\ Brescia
}

\section{Uma abordagem multidisciplinar do ensino: Investigação histórico-arquitectónica da Piazza della Vittoria, Bréscia}

Keywords $\mid$ Palabras clave | Palavras chave

Education, Urban transformation, Exhibition design, Reconstruction models, Documentary research

Educación, Transformación urbana, Diseño de exposiciones, Modelos de reconstrucción, Investigación documental

Educação, Transformação urbana, Desenho de exposições, Modelos de reconstrução, Pesquisa documental

\begin{abstract}
Resumen | Resumo
This paper looks at a multidisciplinary teaching approach for exploring the transformations of Piazza Vittoria in Brescia (Italy) during the fascist era. The approach aims to develop students' grasp of architectural research and to help them take a comprehensive view in an analysis of historical urban planning. The methodology involved studying literature and records. The teaching and learning strategies included face-to-face lectures and multimedia presentations as well as case studies, mapping and data lab groups, workshops and site visits. The students learned to read sources and to decipher documents through descriptive analysis, drawings and photographs so as to build a dataset including intangible memory. The end product involved two exhibitions designed by the students highlighting the transformation of Piazza Vittoria, enabling them to discover the various urban models from antiquity to the designs of Marcello Piacentini. The research project made it possible to rediscover a social aspect of architectural change that had been forgotten over time.

El artículo examina un enfoque didáctico multidisciplinar que explora las transformaciones urbanas de la Piazza della Vittoria de Brescia, en Italia, durante el periodo fascista. Su objetivo es desarrollar el conocimiento de los alumnos en el campo de la investigación arquitectónica y prepararlos para que adquieran una perspectiva global sobre el análisis histórico del urbanismo. Entre las metodologías utilizadas se incluyó la reseña bibliográfica y el estudio de los archivos pertinentes. En cuanto a las estrategias de enseñanza y aprendizaje, se impartieron lecciones presenciales y se hicieron presentaciones multimedia, además de estudios monográficos y cartográficos, grupos de laboratorio de datos, talleres y visitas de campo. Los alumnos aprendieron a leer las fuentes y a interpretar documentos a través del análisis descriptivo, los planos y las fotografías, a fin de elaborar un conjunto de datos que incluyera el patrimonio inmaterial. Cabe
\end{abstract}


destacar como resultado final del trabajo dos exposiciones diseñadas por los alumnos en las que se ponía de relieve la transformación de Piazza Vittoria, lo que les permitió descubrir diferentes modelos urbanos, desde la Antigüedad hasta el proyecto de Marcello Piacentini. Este proyecto de investigación sirvió también para redescubrir un aspecto social del cambio arquitectónico que se había perdido con el transcurso del tiempo.

O artigo examina uma abordagem pedagógica multidisciplinar que explora as transformações urbanas da Piazza della Vittoria, em Bréscia, Itália, durante a era fascista. Tem como objectivo desenvolver a compreensão dos estudantes no domínio da investigação arquitectónica, e prepará-los para a aquisição de uma abordagem abrangente na análise do planeamento histórico-urbano. A metodologia envolveu uma revisão bibliográfica e um levantamento de registos relevantes. As estratégias de ensino e aprendizagem incluíram palestras presenciais e apresentações multimédia, bem como estudos de caso, grupos de mapeamento conceptual e de grupos de laboratório para a análise de dados, oficinas e visitas de estudo. Os estudantes aprenderam a analisar as suas fontes de informação e descodificar documentos através de análise descritiva, desenhos e fotografias, a fim de construir um conjunto de dados que incluía memória intangível. O produto final do trabalho incluiu duas exposições concebidas pelos estudantes que destacaram a transformação da Piazza della Vittoria, permitindo-lhes descobrir diferentes modelos urbanos, desde a antiguidade até ao projecto de Marcello Piacentini. Este projecto de investigação permitiu também redescobrir um aspecto social da mudança arquitectónica que tinha sido perdido com o passar do tempo.

\section{Introduction}

Teaching the history of architectural and urban design continues to play an essential role in design practice and architecture.

This paper looks at how architecture and design students today can learn about the history of architecture and urban design in a way that could help them apply such knowledge in their design practice. This is exemplified with an educational research project carried out in 2016-18 at Liceo Scientifico Statale Leonardo in Brescia. The project was run from the Department of Architecture, Design and the Built Environment, which prepares students for university courses in architecture and design engineering.

Historical sources were used to develop knowledge and skills as well as to help the students discover and understand the importance of the economic, political, cultural and social environment in urban design and architecture. In the project the students investigated the urban and architectural transformation in the fascist era of Piazza della Vittoria (Victory Square) and the redevelopment of Brescia's little-known Pescherie district. In their research the students came to appreciate the role of architecture and urban design in the transformation of the built environment up to the present. The main lesson learned concerned how contemporary urban forms are the product of historical, political, and cultural events and circumstances that influenced and in some cases shaped them. Ultimately the project sought to foster a better understanding of the culture of Brescia and to raise awareness about the historical and urban heritage of the city in which the students live.

\section{Research methodology and objectives}

Teaching design research today involves studying each design project within its context, analysing the urban, historical, political, and socio-cultural background. With this aim we conducted this pilot study with two classes at Liceo Scientifico Statale Leonardo in Brescia. The students researched urban design through problem-based learning, enquiry, creative projects and group collaboration. The selected bibliography influenced their thinking about design, and seminars and workshops contributed to cooperative learning in various complementary ways. The students also explored archives, identifying documents reflecting urban transformations over the history of Brescia. Photographic, cartographic and other tangible archives and libraries were explored. ${ }^{1}$ The students gathered and classified documentation from various sources: maps, plans, depictions, and models.

Physical engagement with buildings and the urban environment outside the classroom also motivated the students. ${ }^{2}$ Outdoors they gathered direct data on the subject and compared them with references, such as metric, photographic and data surveys and bibliographic sources. They made drawings for learning and interpretation, including natural and anthropic elements of the city. 
The project allowed the group to discover a district in which the fascist regime evicted traders such as bakers, butchers, carpenters, pottery makers, clothing designers and manufacturers, glassmakers, photographers, hairdressers, watchmakers and many others. Tangible sources and documents as of the late Roman Empire were also explored, including the design for Piazza Vittoria by the architect Marcello Piacentini (1881-1960).

Drawing upon different sources, such as drawings, photographs and archive maps, the Liceo Leonardo students prepared almost a hundred compositions including tables, architectural models (in 1:200 scale) and a video with virtual reconstructions. The result was a journey through time exploring the history of a district and its square.

The objective of the research was to analyse the components of the urban landscape and to find new data associated with the changing urban design. The students also analysed stages and processes through different periods and identified underlying causes and conditions.

Bylearning about and appreciating the history of architecture and urbanism, students are enabled to think critically and to reflect on appropriate approaches for their own designs.

\section{Studying the early urban history of Brescia}

The students started the project by using primary and secondary data sources to investigate different perspectives on the transformations of Brescia between the $4^{\text {th }}$ and $11^{\text {th }}$ centuries $\mathrm{AD}$. The period was divided into four phases:

Figure 1. Students' graphic restoration of the Imperial Roman map of Brescia

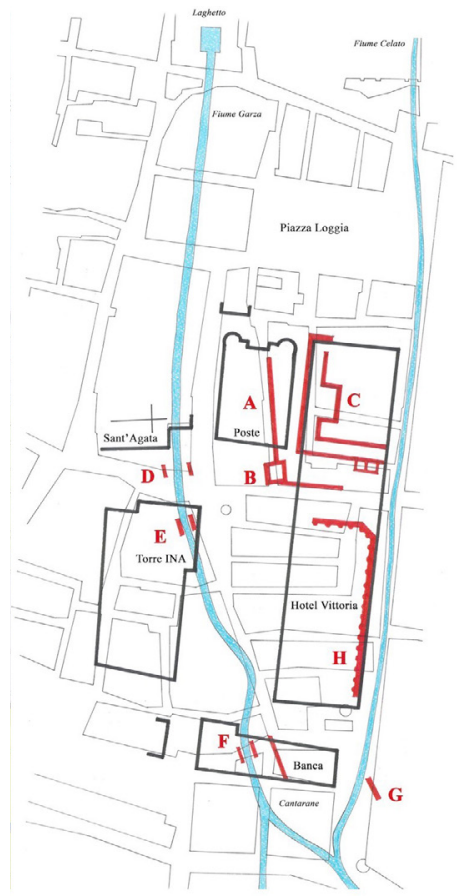

- Late Antiquity ( $4^{\text {th }}$ to $6^{\text {th }}$ century), with the urban issues of the late Roman Empire and the arrival of the Germanic population (the Goths).

- The early Lombard period (568-774), with the advent of the Germanic community and associated rural activities around the city.

- The late Lombard period (mid- $7^{\text {th }}-$-late $8^{\text {th }}$ century), coinciding with the preeminence of the Royal Monastery of San Salvatore.

- The Carolingian age ( $9^{\text {th }}$ century) characterized by the first urban development outside the city walls and around the monastery of San Faustino.

According to Gian Paolo Brogiolo (1993), in the $4^{\text {th }}-5^{\text {th }}$ centuries, Roman Brescia probably had defensive walls, protecting the area between the Castle and San Giuseppe. If we look at a map of ancient Brescia, we see that three rivers, the Garza, Bova and Celato, restricted the expansion of the walls and of the city itself (Fig. 1).

The fortifications along Via X Giornate were interrupted and altered for the construction of Visconti Court. In 1931, during the excavations of Piazza della Vittoria, some of these fortifications were unearthed. The archaeologists found that the walls went from Porta Milanese to the River Garza. They ran from the east to Via X Giornate and south to Porta Paganora. According to Brogiolo (1993: 41), the walls connected two medieval towers, one in Piazza Vittoria and the other built into the palace of Monte di Pieta.

Arnaldo Gnaga (1935) notes that the street plan of Brescia was conditioned by the hills and rivers enclosing the city. Two main roads, running north-south and east-west, intersected in the city center. Gates were built into the fortress walls, chiefly Porta Romana (called Porta Bruciata in the Middle Ages), and later, Porta Milanese. The road link ran from north to south. From the south gate, Porta Torrelunga, the road led to Mantova. The wall at Porta Milanese was seemingly part of a Roman palace, inherited by the Lombard rulers. Via Emilia entered through the arch of Porta Milanese and led out toward Venice through Porta Orientale (called San Andrea and later Porta Venezia). Archaeological ruins from the Roman age were found near Porta Paganora, leading to Cremona and the agriculturally rich Po Valley. Historians believe the site of Piazza Vittoria was occupied by a palace or a horreum colonnade. Indeed, during the excavations of 1929, numerous Roman ruins came to light. Scholars believe Roman walls ran along the bank of the channel of the River Celato, irrigating the meadows to the north. A three-room granary and the remains of a colonnade were also found, $5.5 \mathrm{~m}$ below ground (Gnaga 1935: 75-76; Mirabella 1963: 266-277; Stradiotti 1978: 278-279; Brogiolo 1993: 42) (Fig. 2). 


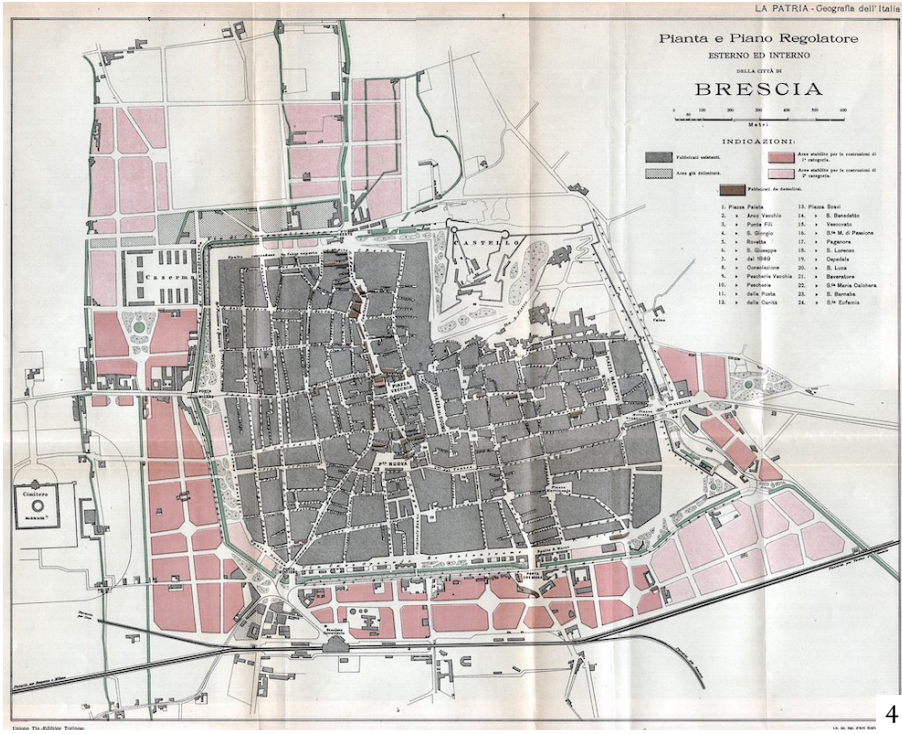

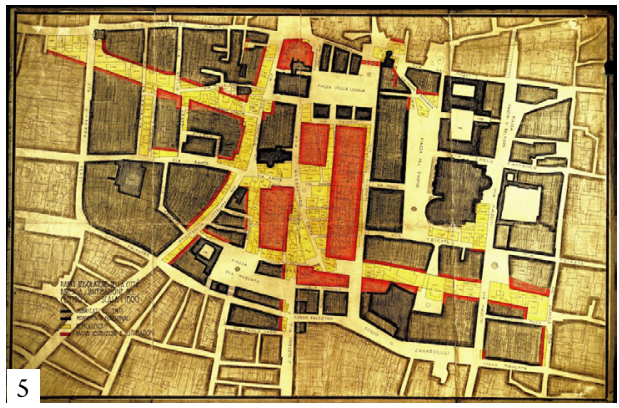

Figure 4. 1897 Brescia Master Plan (Brescia State Archives)

Figure 5. 1930 Brescia Master Plan, designed by Marcello Piacentini (Brescia Town Hall Archives)
It is also interesting to mention the characters involved in these urban projects in Brescia: Augusto Turati, the national secretary of the fascist party, administrator of Brescia and person responsible for the plan, and the industrialist Giulio Togni, a leader of the powerful economic groups which drove and influenced public initiatives. Turati mounted a national competition, announced in 1927 . The architect Marcello Piacentini chaired the jury. Thirteen groups took part and nine projects were accepted. The competition closed in mid-1928 and its results were ratified on 25 October 1928 by the engineer Vittorio Toccolini and the architect Oscar Prati.

The committee members gave six awards for the winning designs and arranged funding for demolition and redevelopment. The winners were three groups of architects and engineers: 1. P. Aschieri, R. Gennari, R. Pisa and G. Venturi; 2. G. Minucci, C. Valle, L. Piccinato, E. Fuselli, E. Faludi, G. Nicolosi, R. Lavagnino, A. Scarpelli and M. Dabbeni; 3. A. Giarratana, A. Bordoni and O. Marchetti.

Adopted on 3 November 1928, the master plan provided for:

- A route to the west toward Milan and to the east toward Venice.

- A route between the north, facing Trento, and the south, toward Cremona.

- Construction of a large square to be called Piazza Vittoria.

- Demolition of buildings adjoining the old cathedral, the Rotonda, and the buildings surrounding the temple of San Faustino in Riposo and Porta Bruciata.
- Demolition of structures at the northern corner of the cathedral.

- Elimination of the roads and buildings by the Pallata tower and toward Corso Garibaldi.

- Elimination of the blocks around Porta Paganora, Via Mazzini and Via Gabriele Rosa.

- Clearance around the church of Sant'Agata and demolition of structures along the Via Aurelio Saffi and Via Umberto I.

- Demolition of the church of San Siro.

- Construction of new city council offices near Largo Tomaso Formentone (Robecchi 1998: 13-47).

Marcello Piacentini himself was in charge of technical and artistic consultancy for this plan. He was responsible for the architectural elements of the new façades and arcades and also designed the buildings to be built around the square. Born in Rome in 1881, the son of the architect Pio Piacentini, by 1907 he had already renovated the nearby cities of Bergamo and Varese in Lombardy. During his career as a fascist commissioner he would later design the campus of La Sapienza University in Rome, in 1932; the EUR district, also in Rome; and in 1938, the city center of Livorno.

Piacentini was interested in both timeless and contemporary urban concepts as well as in infrastructure and transport systems. He travelled widely during his education. He absorbed the language of the proto-rationalism and classicism of the Viennese and German schools, especially the work of Joseph Hoffmann and Joseph Maria Olbrich. He also travelled to the United States to study at the Chicago School. As noted by Beese (2016), Piacentini also 


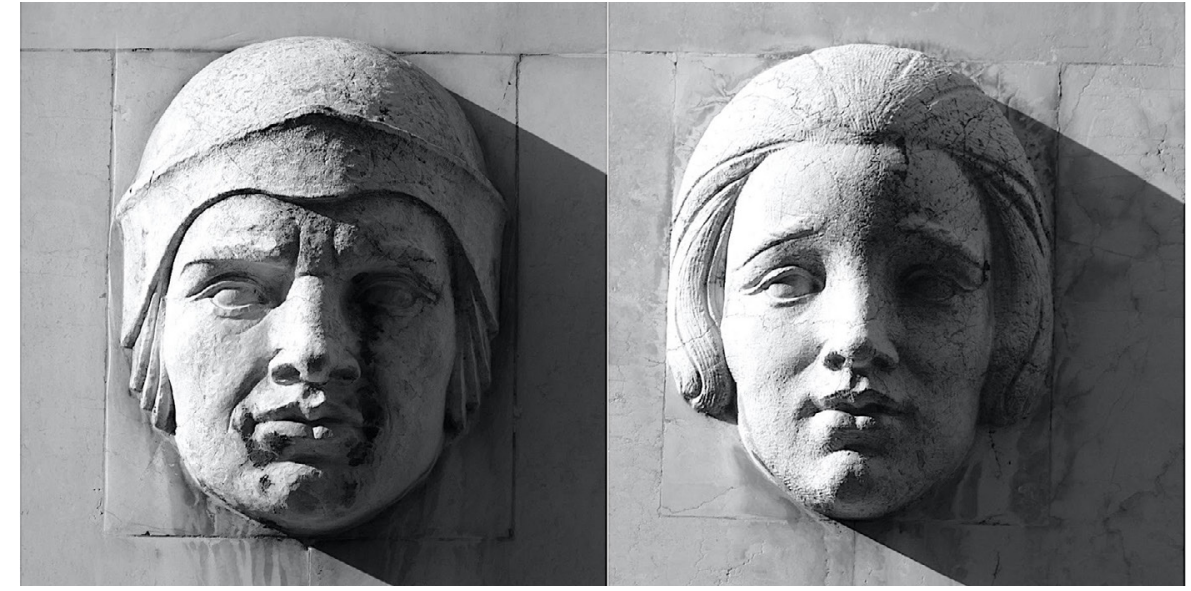

Figure 9. Claudio Botta's work at Hotel Vittoria (Enzo Puglisi) of the tower was a relief by Arturo Martini, unfortunately destroyed by bombing during the Second World War, while the ceramist Vittorio Saltelli modelled the tower's terracotta bas-reliefs, depicting the economic activities of Brescia (Fig. 8 and 8a).

The Banca Commerciale site on the south side of the square is in Palladian style, reinterpreted colossally by Piacentini, while the Palazzo delle Poste and the other buildings by Piacentini evoke the language of the Stuttgart School.

The classical arches of Palazzo della Riunione Adriatica di Sicurtà recall the Doge's Palace in Saint Mark's Square in Venice. Here Corrado Vigni created a low-relief panel with the Lion of Saint Mark. The Riunione Adriatica di Sicurtà building also housed the Cine-Palazzo, the Adria and the Cobianchi hotel. On the ground floor was the Caffè Principe, frescoed by Silvano Tajuti, painter and decorator. The designers Nicolo Berardi and Melchiorre Bega created the interiors and furnishings for most buildings in the square (Robecchi 1998: 172-174).

Toward Piazza della Loggia and Via X Giornate we find the stock exchange halls and the headquarters of the National Social Insurance Fund. The sculptor Claudio Botta designed the high-relief panels of the stock exchange and for Hotel Vittoria he made allegorical marble heads as protomes (Fig. 9). A bronze bas-relief by Romano Romanelli was installed on the façade of the so-called Mussolini tower, also called Revolution Tower. Francesco Nagni and Ercole Drei collaborated on the tower's decorative elements, installing heads of Victory (Robecchi 1998: 180-182) (Fig. 10 and 10a).

On the other side stands the Arengario, a curved podium in Tolmezzo red stone, decorated with nine marble bas-reliefs by Antonio Maraini. The Arengario served as a rostrum for fascist rallies, and Benito Mussolini gave a speech from

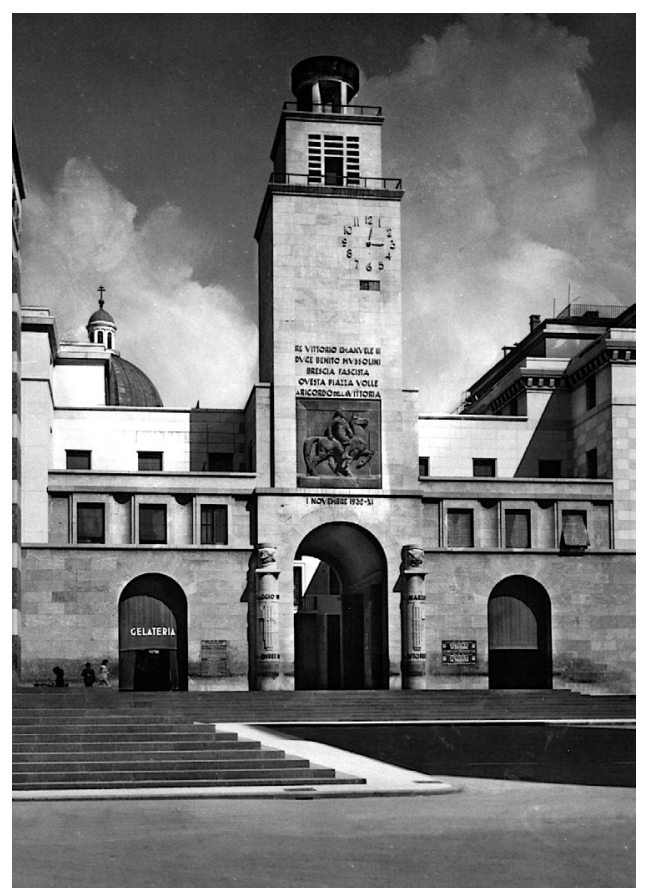

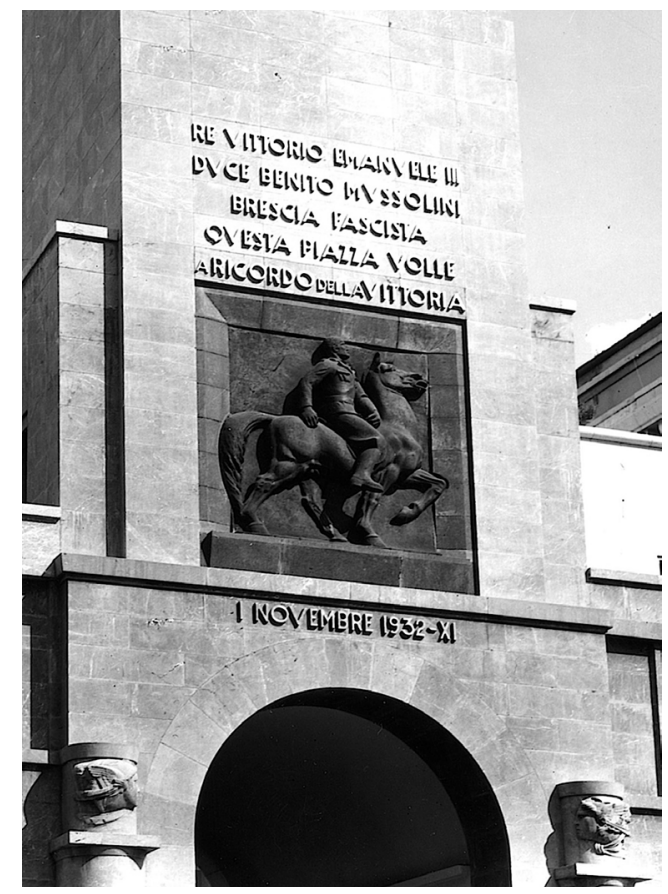

Figure 10 and 10a. Bronze sculpture by Romano Romanelli at the Revolution Tower (Santa Giulia Civici Musei, Brescia) 




Figure 11. Arengario bas-reliefs by Antonio Maraini (Enzo Puglisi)

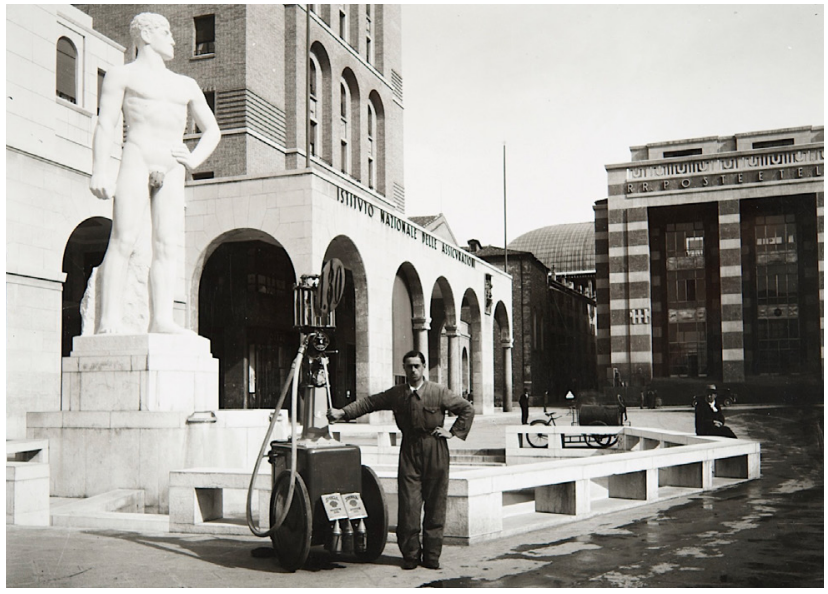

Figure 12. Fascist Era, by Arturo Dazzi (Santa Giulia Civici Musei, Brescia) it at the square's inauguration ceremony in 1932. It is a monument and sculpture steeped in the rhetoric of the fascist regime and yet also serves as a sitting place. Antonio Maraini was an artist much appreciated by the regime and his works include the bronze panels for the main door of the Basilica of San Paolo Fuori le Mura (1929-31) and panels for the new spiral staircase of the Vatican Museums (1932), both in Rome. The Arengario's cycle of bas-reliefs depicts highlights of the history of Brescia in ten framed episodes. It is also the product of a connection with the Roman Littorian style. Anticlockwise: 1) the Roman age; 2) the kingdom of the Lombards; 3) Arnaldo of Brescia; 4) Berardo Maggi and the Signorie; 5) the apparition of Saints Faustino and Giovita in 1438; 6) the artistic Renaissance in Brescia with Gerolamo Romanino and Moretto da Brescia; 7) title page with dedications celebrating the events of the war and the economic strength of Brescia; 8) the Ten Days of Brescia; 9) the First World War; 10) the fascist age (Caramel 1995) (Fig. 11).

The Venice and Trieste Generali Insurance building stands on the west side of the square, with a bronze lion by the sculptor Alfredo Biagini projecting from the façade. Tristano Alberti created the bas-relief on the arcade at the entrance of the Generali building. In the center of a polygonal fountain a statue popularly known as "Bigio" was erected: a large Carrara marble sculpture by Arturo Dazzi (1881-1966) of a naked athlete, entitled Fascist Era. The imposing figure, with its vigorous body, was a metaphor for the power of the fascist regime. Not part of the original project, it was commissioned later by the fascist party. The literature suggests it was originally designed for the Mussolini Forum, but no documents to confirm this hypothesis have been found. Following a terrorist attack, the fountain was ruined and Fascist Era was removed and stored indoors (Giornale di Brescia 1945; Robecchi 2008). Another renowned artist, the Italian Adolf Wildt, created a bust of Benito Mussolini, still preserved in the Brescia Civici Museum (Fig. 12).
The engineer Tito Brusa was in charge of the works in 1927-32. He designed the market building in line with the Vittoria style, surrounded by arches, though this was modified many times over the $20^{\text {th }}$ century. Angelo Righetti produced a sculpture dedicated to Brescia's armed forces, erected in the market rooms of the four-sided portico of Piazza Vittoria but now lost. It overlooked the area of the ancient linen market, with a $19^{\text {th }}$-century fountain designed by $\mathrm{G}$. Donegani. In the square was a statue representing a rhetorical figure of Abundance, designed by the artist G.A. Labus. Here we also find the $18^{\text {th }}$-century Palazzo Martinengo Palatini and the Madonna del Lino church. In the reorganization of the square, the palace of L. Berretta was also altered.

As noted by Gianbattista Tirelli (2018) and Paolo Nicoloso (2018), with the fascist regime, new imposing public building projects were carried out, becaming the setting for Benito Mussolini's pervasive political, dictatorial and anthropological propaganda. Mussolini inaugurated the square on 1 November 1932. However, approval for the square's construction was not unanimous, even among the supporters of fascism. Carlo Belli, for instance, was against it. He lamented the consequences of redeveloping the medieval historical center (Belli 1948). On the other hand, the piazza is today a thriving hub of civic life.

\section{From the Pescherie to San Vincenzo}

In the late $19^{\text {th }}$ century, social questions and public health became issues in Brescia. In 1857 the old slaughterhouse was moved from Contrada delle Beccherie to south of Spalto San Marco. From 1887, various proposals were made for demolitions and urban extensions, the former justified by planning reclassifications.

With Marcello Piacentini's project, Brescia was defined as "free from the impure". Even so, "The neighborhood was made up of dark, damp places inhabited by infamous people 




Figure 13. 1816 Napoleonic map of Brescia (State Archive of Brescia) with graphic reconstruction by the students of the Liceo Scientifico Statale Leonardo: A) Housing, B) Commercial, C) Courtyards

and the poorest part of the population"3 (Piacentini 1932: 61). In spite of the architectural success of Piazza Vittoria, the consequences of the demolition of the medieval part of the Pescherie quarter and the north side of the Carmine district were severe, not only in terms of architecture lost but also economically and socially (Fig. 13 and 13a).

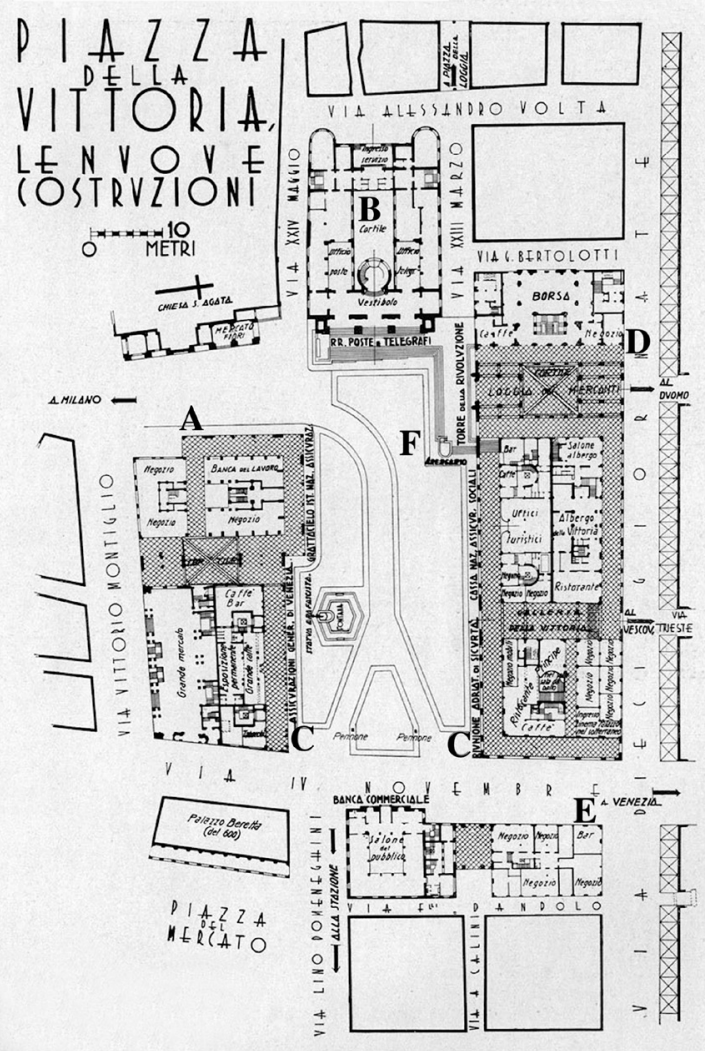

Figure 13a. Original plan by Marcello Piacentini for Piazza della Vittoria: A) INA tower, B) Post office, C) Insurance buildings, D) Stock exchange palace, E) Bank, F) Arengario and Piazza della Vittoria

The social outcomes of the urban plans of 1930 involved a reduction in the population of the historic center, displaced by property speculation with considerable profits for those in power. To raise funds, the city council incurred a large debt also with the municipality of Genoa. In 1928 the works began: 167 buildings and 250 shops, where 2,500 people had worked, were cleared. The total affected population was 760 families, with 2,400 people forced to leave their homes (Fig. 14).



Figure 14. Demolitions in the area (Santa Giulia Civici Musei, Brescia) 

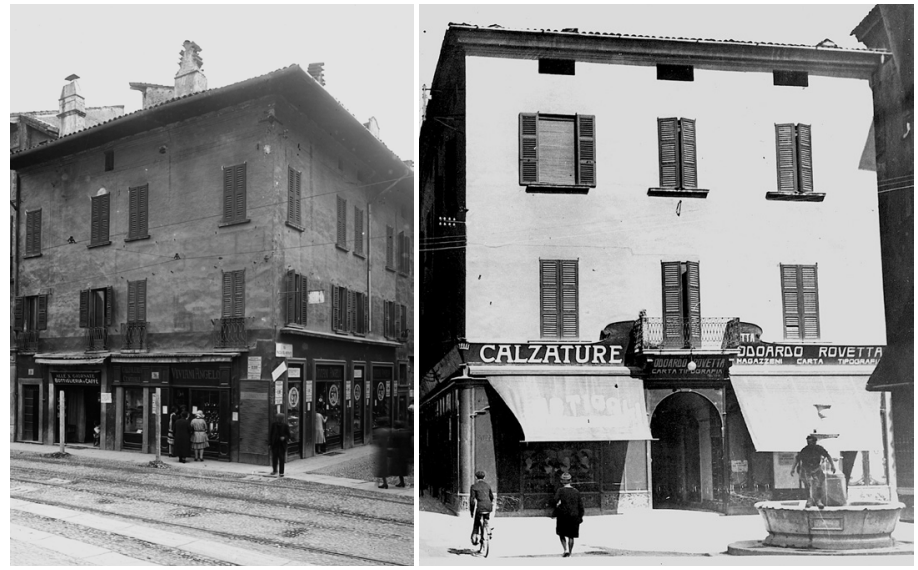

Figure 15 and 15a. Shops and commercial activities in the former urban fabric (Santa Giulia Civici Musei, Brescia)

The district was of medieval origin, densely populated and rich in commerce, especially in food, such as fish, cheese, meat and grains, making it a hive of trade (Fig. 15 and 15a).

The poorest families were temporarily housed in a shanty settlement in the vicinity of Porta Cremona and Campo Marte. Giacomo Vender, a partisan priest, and Father Ottorino Marcolini fought for the dignity and social rights of the thousands evicted by the fascist regime. Later, in the 1960 s, the priests created a "family cooperative" (Coperativa la Famiglia) to support those evicted. In 1931, on the bank of the River Mella, the first residential settlement came into being, with some 15 shacks arranged in four rows.

The temporary district (1929-67) was called the San Vincenzo Camp. The Institute for Public Housing soon devised a solution to the problem. In 1937 a rural area of $22,000 \mathrm{~m} 2$ was purchased for 16 semi-detached houses and 32 apartments. Unfortunately, in 1940, these lodgings were handed over to Italians returning from France.

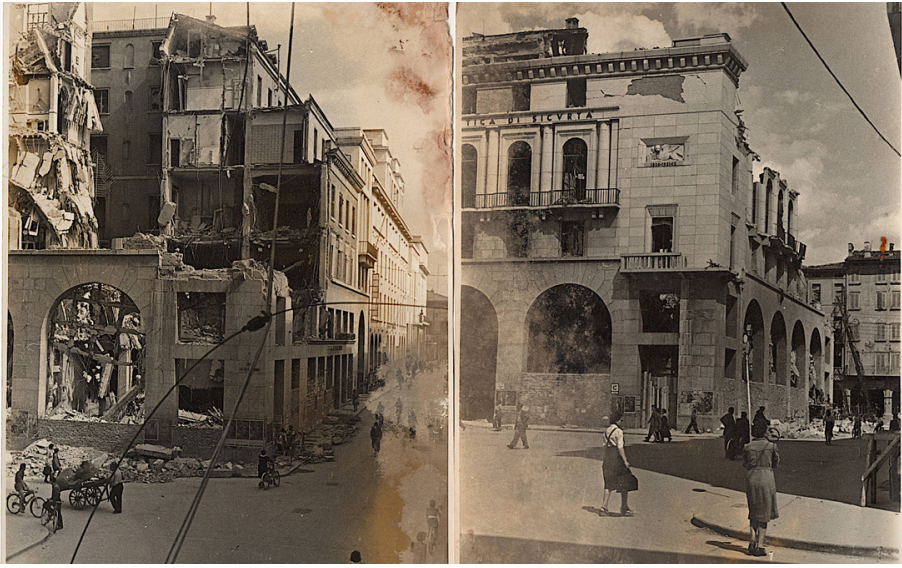

Figure 16 and 16a. The bombing of Piazza della Vittoria in 1943-44 (State Archive of Brescia)

Together with the municipality, the local San Vincenzo Conference built the first shacks. The district took the name of San Vincenzo and was known as sbandi sfrattati (the homeless village). It consisted of 13 buildings, each divided into 20 rooms of about $25 \mathrm{~m} 2$, with an entrance door, a window and earthen flooring. Each family had one room, though if a family had more than seven members, it was assigned two rooms. There was no indoor drinking water, gas or electricity. There were outdoor fountains and 40 latrines for more than a thousand people. In 1931 other buildings were added: an elementary school, a clinic, a craft workshop and a caretaker's house. When the "village" was completed, 250 families moved in.

Giacomo Vender was the parish priest, an important figure dedicated to the socio-cultural and educational instruction of young people. He worked hard to find them jobs and set up a children's choir and the Choir of San Vincenzo. He also supported sports activities and artisan workshops.
Figure 17. Excavations in the Vittoria Underground Station (Brescia Mobility Archive)




The new quarter, San Vincenzo, became a little town with activities such as craft shops, a cobbler's shop, a bakery and a greengrocer's. The community survived the war and continued the prolific cultural project initiated by Giacomo Vender (Foresta 2015).

\section{Later developments in Piazza Vittoria}

In the Second World War Brescia was bombed extensively. The first bombing was on 14 February 1944, by the Allies. As of 13 July 1944 there were dozens of attacks, leaving 1,302 dead, many injured, 600 buildings destroyed and 5,550 damaged. There were 28,000 war-displaced citizens just in Brescia. The first bombing of Piazza Vittoria was on 14 February 1944 and other bombings followed on 24 March 1945, 2 February 1945 and 4 April 1945 (Fig. 16 and 16a).

Given the lack of funding for the urban redevelopment of 1929-1930, the project had to be put on hold and was only partly completed. In the reconstruction after the Second World War, the square was largely abandoned until the economic and industrial upturn of the 1960s. Since then Piazza Vittoria has been much frequented by people, and also by many forms of transport. In 1974 a large underground car park was built (a common feature of Italian cities after 1960), which unfortunately involved large ventilation grilles being fitted at ground level. Finally in 2013 an underground station was opened and the area closed to other vehicles, making room for new street life.

In July 2008, during a metro excavation, the discovery of a notable structure was reported: a building facing the south side of the church of Sant'Agata - a $12^{\text {th }}$-century tower set on a stone base about $1 \mathrm{~m}$ high with traces of Medolo stone formwork. Its walls are almost $1.5 \mathrm{~m}$ thick. It was probably altered in medieval times so as to create a vaulted barrel cellar and two-floor entrances. The tower was part of a demolished block overlooking the intersection of Via Dante and Corsetto di Sant'Agata. In 2008, after some debate, the option of preserving the remains of the tower prevailed. The masonry was cut into blocks, sized for lifting by crane. The blocks were stored and covered with sand and are still awaiting relocation (Fig. 17).

Figure 19. Hypothetical reconstruction of the old quarter: A) Old Pescherie Square, B) X Giornate Street

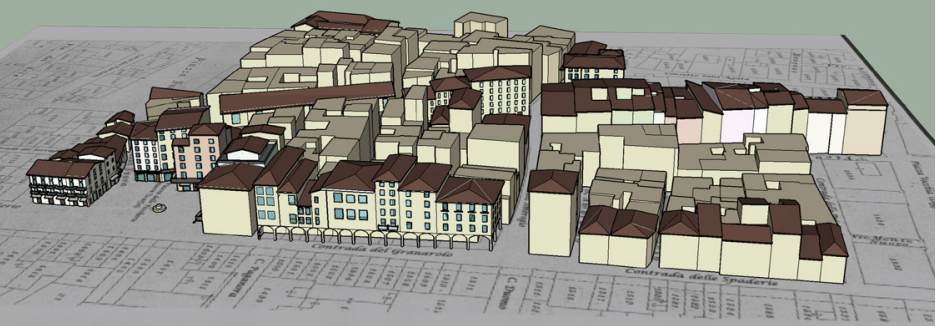

Today the main post office is still functioning in the square, the commercial premises thrive and the piazza has become one of the core urban spaces of Brescia, enlivened by numerous events such as an antiques and books market, guided tours, and music and sports events.

\section{Conclusion: Final results and exhibition design}

The students explored ideas and generated alternatives with drawings and 3D models allowing them to make selections and to find the best options. The analytical method involved a specific procedure as shown below:

\begin{tabular}{|c|c|c|}
\hline METHOD & $\begin{array}{l}\text { DIDACTIC } \\
\text { TOOLS }\end{array}$ & RESULTS \\
\hline $\begin{array}{l}\text { Bibliographic } \\
\text { Research }\end{array}$ & $\begin{array}{l}\text { Drawings and } \\
\text { elevations }\end{array}$ & Illustrative tables \\
\hline $\begin{array}{l}\text { Historical } \\
\text { Research }\end{array}$ & Graphic design & Descriptive tables \\
\hline Archival Research & $\begin{array}{l}\text { Photographic } \\
\text { survey }\end{array}$ & $\begin{array}{l}\text { Plastic 3D virtual } \\
\text { models }\end{array}$ \\
\hline $\begin{array}{l}\text { Photographic } \\
\text { Archives Research }\end{array}$ & $\begin{array}{l}\text { Metric relief } \\
\text { and metric scale } \\
\text { deduction }\end{array}$ & $\begin{array}{l}\text { Animated video } \\
\text { production }\end{array}$ \\
\hline $\begin{array}{l}\text { Surveys in } \\
\text { Institutions }\end{array}$ & $\begin{array}{l}3 \mathrm{D} \text { modelling } \\
\text { rendering }\end{array}$ & Exhibition design \\
\hline $\begin{array}{l}\text { Topographic } \\
\text { \& Urbanistic } \\
\text { Surveys }\end{array}$ & SketchUp & $\begin{array}{l}\text { Design thematic } \\
\text { tables }\end{array}$ \\
\hline Mapping & $\begin{array}{l}\text { CAD and } \\
\text { AutoCAD }\end{array}$ & Guided tours \\
\hline $\begin{array}{l}\text { Geo-portal of } \\
\text { Brescia }\end{array}$ & Editing design & Public conferences \\
\hline
\end{tabular}

Figure 18. Reconstruction of Mercanti Street by the students of the Liceo Scientifico Statale Leonardo

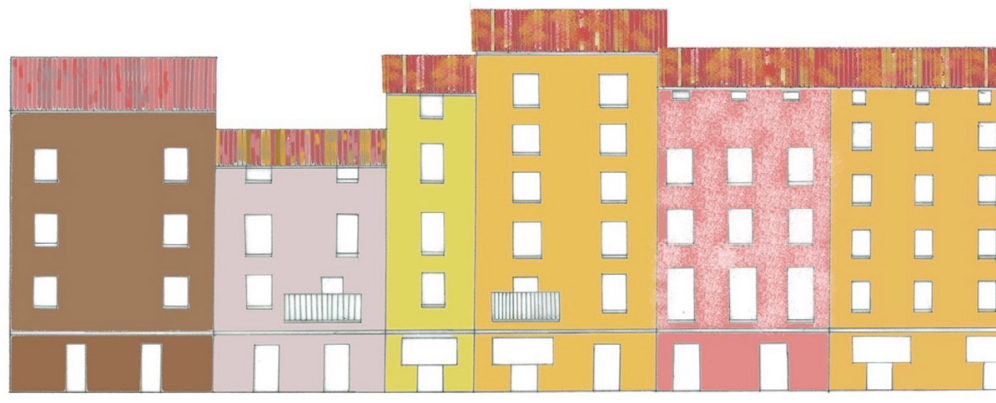

Corso dei Mercanti 


\section{Bibliography $\mid$ Bibliografía | Bibliografia}

Beese, Christine. 2016. Grand Tour in Reverse: Marcello Piacentini's Tour of Germany in 1930 and 1931. Architectural Histories, vol.4, 1: 16 doi: http://doi.org/10.5334/ah.197

Belli, Carlo. 1948. I pericoli della retorica, Il Tempo, September 23.

Brogiolo, Gian Pietro. 1993. Brescia altomedievale. Urbanistica ed edilizia dal IV al IX secolo. Documenti di Archeologia, 2: 9-33. Mantova: Società archeologica padana.

Caramel Luciano. 1995. Antonio Maraini a Brescia. I modelli in gesso e disegni per l'arengario di piazza della Vittoria. Brescia: Litografia Eredi F. Salami.

Violante Cinzio. 1963. La Chiesa Bresciana. Storia di Brescia, vol. 1, XVIII: 1105. Brescia: Treccani.

Ciucci, Giorgio; and Muratore, Giorgio. 2004. Storia dell'architettura italiana. Il primo Novecento. Milano: Mondadori.

Foresta, Rossana. 2015. Gli Sfrattati di Brescia e la memoria corta. Brescia: Stampa Futura.

Giornale di Brescia. 1945. Attorno a una statua (Molto rumore per nulla), July 10.

Giornale di Brescia. 2016. Scoperta e finita in esilio: la torre medievale cerca un destino. November 6, https://www.giornaledibrescia.it/ brescia-e-hinterland/scoperta-e-finita-in-esilio-la-torre-medievalecerca-un-destino-1.3129719 (consulted on 20/07/2020).

Gnaga, Arnaldo. 1935. Scavi per la piazza della Vittoria e la topografia romana di Brescia. Commentari Ateneo Brescia 1935: 73-91. Brescia: Ed. F.lli Apollonio.

Mirabella, Roberti Mario. 1963. Archeologia e arte di Brescia romana, 1: 231-320. Brescia: Morcelliana.

Muntoni, Alessandra. 2010. Marcello Piacentini e l'Europa, retroguardia e rinnovamento. In Ciucci, Giorgio; Lux, Simonetta; and Purini, Franco (eds.). Marcello Piacentini architetto 1881-1960, 53-73. Roma: Gangemi.

Nicoloso, Paolo. 2018. Marcello Piacentini. Architettura e potere: una biografia. Udine: Gaspari.

Piacentini, Marcello. 1932a. Il nuovo centro di Brescia. Illustrazione Italiana, October 30: 634-635.

Piacentini, Marcello. 1932b. Notizie tecniche e statistiche sulla costruzione di Piazza della Vittoria. Architettura, 12: 649-673.

Robecchi, Franco. 1983. Uomini vicende imprese nell'economia bresciana, vol. 1. Brescia: Industria Grafica Bresciana.

Robecchi, Franco. 1998. Brescia littoria: una città modello dell'urbanistica fascista. Roccafranca, Brescia: La Compagnia della Stampa.

Robecchi, Franco; and Treccani, Gian Paolo. 1993. Piazza della Vittoria. Brescia: Grafo.

Robecchi, Franco. 2008. Brescia e il colosso di Arturo Dazzi. Roccafranca, Brescia: La Compagnia della Stampa.

Sabatino, Michelangelo. 2010. Pride in Modesty: Modernist Architecture and the Vernacular Tradition in Italy. Toronto: The University of Toronto Press.

Stradiotti, Renata. 1978. Piazza della Vittoria, in Panazza Gaetano. Il Volto Storico di Brescia, vol. 3: 278-316. Brescia: Grafo.

Tirelli, Gianbattista. 2018. Piazza della Vittoria e Era fascista. Brescia: Fondazione Luigi Micheletti.

\section{Biographies | Biografías $\mid$ Biografias}

\section{Nadia Campadelli}

Nadia is a teacher of art and design with expertise in several fields including contemporary architecture, design and art, museums, libraries and archives, history and science. Her educational background includes a $\mathrm{PhD}$ in strategic design for cultural institutions from Politecnico di Milano. She holds a master's in conservation of paintings and artworks and a bachelor's degree in archaeology and visual arts, both from Università Cattolica del Sacro Cuore, Milan. She is currently living in Cambridge, UK, studying for a PgDip/MSc in Charity Marketing and Fundraising at CASS Business School (London).

\section{Enzo Puglisi}

Enzo is a teacher of Architecture and the Built Environment in the Italian Education System. He holds a Degree in History of Art and Archaeology: Cultural Heritage, Stage Design and Scenography. He is a researcher at "Learning from the Past", KA2 Erasmus+, Global Link, Lancaster, UK. He has been a visiting teacher of Language and Culture at Sonoma State University (California) and a collaborator at the Micheletti Foundation (Brescia), Pagine Editor (Rome), and ALI Penna d'Autore (Turin). A poet, artist and photographer, through the power of imagination, gesture and engaged contemplation, Enzo looks on the world from diverse perspectives. 